\title{
APA YANG MENDORONG DIVERSIFIKASI PENDAPATAN PETANI?: TINJAUAN EMPIRIS RUMAH TANGGA TANI PADI PROVINSI JAWA TIMUR
}

\author{
(What are The Drivers of Farmers' Income Diversification?: Empirical Review on Rice \\ Farm Households in East Java Province)
}

\author{
Gilang Wirakusuma \\ Departemen Sosial Ekonomi Pertanian, Universitas Gadjah Mada, Yogyakarta \\ Email: gilang_wirakusuma@ugm.ac.id
}

Diterima 12 oktober 2019, disetujui 21 Mei 2020

\begin{abstract}
ABSTRAK
Diversifikasi pendapatan merupakan salah satu strategi rumah tangga tani untuk memaksimalkan penggunaan sumber daya yang didasari berbagai motif. Penelitian ini dilakukan untuk mengukur tingkat diversifikasi pendapatan pada rumah tangga tani padi serta mengidentifikasi faktor penentu pada diversifikasi yang mereka lakukan. Dengan menggunakan data pada level rumah tangga, tingkat diversifikasi dianalisis dengan formula Indeks Keberagaman Simpson (IKS). Sementara itu, identifikasi faktor penentu diversifikasi pendapatan diuji dengan metode Censored Tobit Regression. jLebih lanjut, tingkat diversifikasi pendapatan secara signifikan ditentukan oleh faktor-faktor yang berasal dari aspek karakteristik rumah tangga, usahatani, kepemilikan asset, institusi, dan ketersediaan pangan rumah tangga.

Kata Kunci: Censored Tobit Regression, Diversifikasi Pendapatan, Indeks Kebergaman Simpson, Provinsi Jawa Timur, Rumah Tangga Tani Padi
\end{abstract}

\begin{abstract}
Income diversification is one of the strategies of farm households to maximize the resources utilization based on various motives. This research was conducted to measure the level of income diversification in rice farm households and identify the determining faktors of the income diversification. Using data at the household level, the income diversification was measured by the Simpson Diversity Index (SDI). Meanwhile, the identification of the determinants of income diversification was analyzed with the Censored Tobit Regression method. The result shows that the degree of income diversification of rice farm household in East Java Province is relatively low. Nevertheless, SDI still indicates that rice farm households earn their income from diverse sources of livelihood. Furthermore, the level of income diversification is significantly determined by household characteristics, farm, assets ownership, institutions, and perception on household food availability.
\end{abstract}

Keywords: Censored Tobit Regression, East Java Province, Income Diversification, Rice Farm Households, Simpson Diversification Index

\section{PENDAHULUAN}

Secara global, pertanian menyumbang $67 \%$ dari lapangan kerja, berkontibusi sebesar $39,4 \%$ dalam produk domestik bruto nasional, dan memiliki proporsi sebesar 43\% dalam volume barang ekspor (FAO, 2015). Populasi dunia terus tumbuh dan diperkirakan akan mencapai 9,7 miliar pada tahun 2050 (UN, 2015). Oleh karena itu, permintaan akan 
keamanan pangan dan mata pencaharian menjadi perhatian utama perencana dan peneliti pembangunan. Sementara itu, di Indonesia, sekitar 33\% angkatan kerja bekerja di sektor pertanian. Namun, sebagian besar rumah tangga pertanian di Indonesia adalah petani kecil. Jumlah rumah tangga petani kecil di Indonesia adalah 14.250.000 rumah tangga atau $55,53 \%$ dari total rumah tangga pertanian di Indonesia (Bappenas, 2014).

Bagi petani kecil, pertanian yang berisiko tinggi mendorong mereka untuk mencari sumber pendapatan alternatif walaupun kegiatan dengan upah yang rendah dan berisiko tinggi (Barrett et al., 2001). Rumah tangga petani yang merupakan petani skala kecil umumnya menggabungkan beragam aktivitas ekonomi untuk lepas dari jerat kemiskinan dan meningkatkan standar hidup (Alobo Loison, 2015). Dalam hal ini, terminologi perilaku rumah tangga tani itu disebut sebagai diversifikasi. Seperti yang didefinisikan oleh Ellis (2008), diversifikasi mata pencaharian mengacu pada proses di mana rumah tangga mengumpulkan berbagai kegiatan dan sistem dukungan sosial untuk menangani keterbatasan kapasitas produksi dan meningkatkan kesejahteraan mereka. Bagi sebagian besar petani kecil, diversifikasi yang melibatkan sector di luar pertanian menyumbang $30-40 \%$ dari pendapatan keseluruhan mereka (Alobo Loison, 2015; Ellis, 1998). Diversifikasi mata pencaharian merupakan strategi kunci yang berkaitan dengan level kegiatan ekonomi suatu rumah tangga (Start, 2001). Diversifikasi mata pencaharian merupakan salah satu strategi untuk mengelola dan mengurangi risiko bisnis bagi rumah tangga pertanian (Dercon, 2002; Ellis, 1998; Zhao \& Barry, 2014). Sementara itu, bagi petani yang relatif kaya dan mengelola pertanian yang menghasilkan profit tinggi, diversifikasi mata pencaharian dilandasi oleh motif untuk menambha kekayaan atau asset (Alobo Loison, 2015; Haggblade et al., 2010; Lanjouw \& Lanjouw, 2001). Dengan demikian, diversifikasi bukan hanya dikaitkan tujuan rumah tangga untuk menjaga kelangsungan hidup dalam kondisi ekonomi yang buruk, tetapi juga dijadikan strategi untuk meningkatkan pendapatan dalam kondisi ekonomi yang membaik (Niehof, 2004).

Diversifikasi mata pencaharian diklasifikasikan dalam berbagai cara. Pertama, rumah tangga pertanian secara eksklusif bergantung pada produksi pertanian mereka sendiri untuk memperoleh pendapatan, yang mana digolongkan sebagai full time farmer. Kedua, rumah tangga pertanian mengkombinasikan kegiatan produksi di lahan mereka sendiri dan bekerja sebagai buruh pertanian di lahan petani lainnya. Strategi ketiga adalah bekerja sebagai pengelola lahan pertanian sendiri dan bekerja di sektor non-pertanian. Keempat, rumah tangga pertanian menggabungkan ketiga elemen dasar yang telah dibahas sejauh ini: produksi pertanian on-farm, bekerja sebagai buruh pertanian, serta berkegiatan di luar sektor pertanian (Ellis, 1998; Kassie, 2017; Nguyen et al., 2019)

Secara parsial, studi-studi tentang penentu diversifikasi pendapatan telah dilakukan beberapa peneliti di berbagai negara. Aspek yang mendorong suatu rumah tangga petani untuk berpartisipasi dalam berbagai kegiatan ekonomi antara lain demografi, sosial budaya, ekonomi, dan guncangan yang tidak terprediksi (Adelekan \& Omotayo, 2018; Kerua, 2019; Mishra \& Moss, 2013; Nguyen et al., 2019; Schwarze \& Zeller, 2005; Wan et al., 2016; Xing, 2018) Walaupun demikian, kebanyakan penelitianpenelitian tersebut mengklasifikasikan matapencaharian dalam kategori pertanian dan non-pertanian. Oleh sebab itu, perlu untuk melakukan analisis diversifikasi yang melibatkan berbagai klasifikasi kegiatan ekonomi rumah tangga petani, baik yang berada aspek on-farm (diversifikasi komoditas) dan non-pertanian. Pada akhirnya, nilai diversifikasi pendapatan rumah tangga tani akan dibentuk secara holistik.

Sebagaimana telah dijelaskan sebelumnya, bahwa karakteristik umum usahatani yang dikelola oleh rumah tangga pertanian di Indonesia adalah pertanian skala 
kecil. Lebih lanjut, diversifikasi pendapatan merupakan salah satu strategi yang dipilih oleh rumah tangga pertanian skala kecil untuk mengoptimalkan sumber matapencahariannya dalam rangka memenuhi kebutuhan hidup dan mencapai kesejahteraan. Berdasarkan hal tersebut, penelitian ini dilakukan dengan tujuan untuk: (1) mengukur tingkat diversifikasi pendapatan pada level rumah tangga tani dengan melibatkan variasi sumber pendapatan pada kegiatan pertanian dan nonpertanian serta (2) mengidentifikasi faktor pendorong bagi mereka untuk melakukan diversifikasi pendapatan tersebut. Dengan demikian, penelitian ini akan memberikan pemahaman lebih lanjut mengenai alternatifalternatif yang dipilih oleh rumah tangga pertanian di Indonesia untuk meningkatkan pendapatan dari berbagai sumber daya yang mereka miliki.

\section{METODE PENELITIAN}

\section{Lokasi dan Data}

Penelitian ini memilih rumah tangga tani padi sebagai sampel analisis. Hal ini didasari oleh dominasi rumah tangga petani yang menjadikan padi sebagai komoditas utama, yang mana jumlah rumah tangga petani yang membudidayakan padi adalah sekitar 14,1 juta rumah tangga (Bappenas, 2014). Sementara itu, lokasi penelitian ini adalah Provinsi Jawa Timur dimana daerah ini merupakan kawasan yang memiliki luas tanam dan produksi padi terbesar di Indonesia, yaitu 1,55 juta hektar lahan dan 13,1 juta ton (Badan Pusat Statistik, 2015). Selanjutnya, penelitian ini menggunakan sebanyak 38.911 sampel yang diperoleh dari datamikro Sensus Pertanian 2013 yang dilaksanakan oleh Badan Pusat Statistik. Sampel dipilih secara multistage random sampling dengan memperhatikan lokasi dan persebaran sampel di masing-masing kabupaten/kota di Provinsi Jawa Timur.

\section{Metode Analisis}

Indeks Keragaman Simpsons digunakan dalam penelitian ini untuk memengukur tingkat diversifikasi pendapatan di antara rumah tangga petani padi di Provinsi Jawa Timur. IKS mempertimbangkan baik jumlah sumber pendapatan maupun seberapa meratanya distribusi pendapatan dari berbagai sumber (Minot, Epprecht, Anh, \& Trung, 2006). Nilai IKS berkisar antara nol (0) dan satu (1). Jadi, 0 menunjukkan spesialisasi dan 1 diversifikasi mutlak. Jika nilai IKS semakin mendekati 1, maka sumber pendapatan atau aktivitas produktif yang dijalankan oleh rumah tangga petani semakin beragam.

Formulasi perhitungan IKS adalah sebagai berikut (Agyeman et al., 2014):

$$
I K S=1-\sum_{(i=1)}^{n} A_{i}^{2} \ldots
$$

IKS adalah Indeks Keragaman Simpsons, $\mathrm{n}$ menunjukkan jumlah sumber pendapatan, Ai berarti proporsi pendapatan yang diperoleh dari sumber i. Kegiatan produktif yang menjadi sumber pendapatan rumah tangga pertanian terdiri dari kegiatan pertanian, nonpertanian, maupun dana transfer yang diperoleh dari anggota keluarga, program pemerintah, atau pihak lainnya (Ellis, 1998). Dalam penelitian ini, sumber pendapatan (i) yang dijadikan sebagai acuan analisis antara lain: (1) budidaya padi, (2) budidaya palawija, (3) budidaya hortikultura, (4) budidaya tanaman perkebunan, (5) pemeliharaan ternak, (6) hasil perikanan, (7) pengolahan hasil pertanian, (8) pengolahan hasil non-pertanian, (9) tambang/galian, (10) konstruksi, (11) perdagangan, (12) transportasi, (13) dana pensiun, (14) dividen, dan (15) remitansi. Sumber pendapatan tersebut merupakan dekomposisi dari pendapatan pertanian (1-6), non-pertanian (712), dan transfer (13-15) sebagaimana ketersediaan informasi di dalam survey pendapatan Sensus Pertanian 2013 Badan Pusat Statistik.

Model Censored Tobit Regression digunakan untuk mengidentifikasi faktorfaktor yang menentukan keterlibatan rumah tangga pertanian dalam diversifikasi pendapatan. Kehadiran nol dalam variabel dependen, IKS, pada beberapa responden 
(sehingga tidak menunjukkan diversifikasi)

menuntut penggunaan Censored Tobit

Regression. Formulasi umum untuk spesifikasi Tobit adalah sebagai berikut (Green, 2003):

$y_{i}^{*}=\beta x_{i}+\varepsilon_{i}$

$y_{i}=0$ if $y_{i}^{*} \leq 0$

$y_{i}=y_{i}^{*}$ if $y_{i}^{*}>0$

Pada formula tersebut, $y_{i}{ }^{*}$ menunjukkan variabel IKS yang telah disensor, $\beta$ adalah parameter yang dihasilkan oleh estimasi, $x$ merepresentasikan variabel penjelas, dan $\varepsilon$ adalah standard error.

\section{HASIL DAN PEMBAHASAN}

Distribusi rumah tangga tani padi pada berbagai sumber pendapatan

Pada penelitian ini, sampel yang digunakan adalah rumah tangga petani yang membudidayakan padi. Secara keseluruhan, selain budidaya padi, terdapat empat belas (14) sumber pendapatan lainnya yang berasal dari sektor pertanian, non-pertanian, dan transfer. Berdasarkan kategorisasi diketahui bahwa mayoritas rumah tangga petani padi di Provinsi Jawa Timur memiliki usaha ternak $(60,36 \%)$. Kegiatan usaha ternak sangat berkaitan dengan integrasi pertanian, yang mana output sampingan atau waste dari budidaya padi dan ternak dapat dimanfaatkan sebagai input bagi kedua kegiatan tersebut.

Tabel 1. Definisi dan Pengukuran Variable Penjelas $(x)$

\begin{tabular}{|c|c|c|c|c|}
\hline $\begin{array}{c}\text { Variabel } \\
\text { penjelas }(x)\end{array}$ & Definisi/Deskripsi & $\begin{array}{c}\text { Pengukuran / Unit } \\
\text { Satuan }\end{array}$ & $\begin{array}{l}\text { Hipotesis } \\
\text { pada } \\
\text { hubungan } \\
y \text { dan } x_{i}\end{array}$ & Referensi \\
\hline Gender $\left(\mathrm{x}_{1}\right)$ & $\begin{array}{l}\text { Jenis kelamin kepala } \\
\text { rumah tangga }\end{array}$ & $\begin{array}{l}=1 \text { jika laki-laki, }=0 \\
\text { jika perempuan }\end{array}$ & - & \\
\hline $\operatorname{Usia}\left(\mathrm{x}_{2}\right)$ & $\begin{array}{l}\text { Usia kepala rumah } \\
\text { tangga }\end{array}$ & tahun & + & \\
\hline $\begin{array}{l}\text { Pendidikan } \\
\left(\mathrm{x}_{3}\right)\end{array}$ & $\begin{array}{l}\text { Tingkat pendidikan } \\
\text { kepala rumah tangga }\end{array}$ & $\begin{array}{l}=1 \text { jika lulus } \\
\text { minimal } \\
\text { SMA/sederajat, } \\
=0 \text { jika kurang dari } \\
\text { SMA/sederajat }\end{array}$ & + & $\begin{array}{l}\text { (Bezu et al., } \\
\text { 2012; Ellis, } \\
\text { 1998) }\end{array}$ \\
\hline $\begin{array}{l}\text { Anggota } \\
\text { rumah } \\
\text { tangga }\left(\mathrm{x}_{4}\right)\end{array}$ & $\begin{array}{l}\text { Jumlah anggota } \\
\text { rumah tangga yang } \\
\text { tinggal di rumah yang } \\
\text { sama dengan kepala } \\
\text { rumah tangga }\end{array}$ & orang & + & \\
\hline Lahan $\left(\mathrm{x}_{5}\right)$ & $\begin{array}{l}\text { Luas lahan pertanian } \\
\text { yang dikuasai }\end{array}$ & $\mathrm{m}^{2}$ & - & $\begin{array}{l}\text { (Niguissie et al., } \\
2017 \text {; } \\
\text { Woldehana, } \\
\text { 2002) }\end{array}$ \\
\hline $\begin{array}{l}\text { Hambatan } \\
\text { input }\left(\mathrm{x}_{6}\right)\end{array}$ & $\begin{array}{l}\text { Persepsi / } \\
\text { pengalaman pada } \\
\text { hambatan } \\
\text { memperoleh sarana } \\
\text { produksi selama } \\
\text { periode pencatatan }\end{array}$ & $\begin{array}{l}=1 \text { jika mengalami } \\
\text { kesulitan saprodi, } \\
=0 \text { jika tidak } \\
\text { mengalami }\end{array}$ & + & (Kassie, 2017) \\
\hline
\end{tabular}




\begin{tabular}{|c|c|c|c|c|}
\hline Kredit $\left(\mathrm{x}_{7}\right)$ & $\begin{array}{l}\text { Penggunaan kredit } \\
\text { untuk modal usahatani }\end{array}$ & $\begin{array}{l}=1 \text { jika } \\
\text { menggunakan, } \\
=0 \text { jika tidak } \\
\text { menggunakan }\end{array}$ & - & $\begin{array}{l}\text { (Ellis, 2008; } \\
\text { Niguissie et al., } \\
\text { 2017) }\end{array}$ \\
\hline $\begin{array}{l}\text { Penyuluhan } \\
\left(\mathrm{x}_{8}\right)\end{array}$ & $\begin{array}{l}\text { Partisipasi dalam } \\
\text { kegiatan penyuluhan } \\
\text { pertanian oleh kepala } \\
\text { atau anggota rumah } \\
\text { tangga }\end{array}$ & $\begin{array}{l}=1 \text { jika } \\
\text { berpartisipasi, } \\
=0 \text { jika tidak } \\
\text { berpartisipasi }\end{array}$ & - & (Ellis, 2008) \\
\hline $\begin{array}{l}\text { Keanggotaan } \\
\text { kelompok } \\
\text { tani }\left(\mathrm{x}_{9}\right)\end{array}$ & $\begin{array}{l}\text { Keanggotaan/partisipasi } \\
\text { dalam kelompok tani } \\
\text { oleh kepala atau } \\
\text { anggota rumah tangga }\end{array}$ & $\begin{array}{l}=1 \text { jika anggota } \\
\text { kelompok tani, } \\
=0 \text { jika bukan } \\
\text { anggota }\end{array}$ & + & $\begin{array}{l}\text { (Abeje et al., } \\
\text { 2019; Kassie et al., }\end{array}$ \\
\hline $\begin{array}{l}\text { Keanggotaan } \\
\text { koperasi }\left(\mathrm{x}_{10}\right)\end{array}$ & $\begin{array}{l}\text { Keanggotaan/partisipasi } \\
\text { dalam koperasi oleh } \\
\text { kepala atau anggota } \\
\text { rumah tangga }\end{array}$ & $\begin{array}{l}=1 \text { jika anggota } \\
\text { koperasi, }=0 \text { jika } \\
\text { bukan anggota } \\
\text { koperasi }\end{array}$ & + & 2017) \\
\hline \multirow{4}{*}{$\begin{array}{l}\text { Kepemilikan } \\
\text { asset }\left(\mathrm{x}_{11}, \mathrm{x}_{12}\right. \\
\left.\mathrm{x}_{13}, \mathrm{x}_{14}\right)\end{array}$} & $\begin{array}{l}\text { Luas area yang } \\
\text { digunakan untuk rumah } \\
\text { tempat tinggal }\end{array}$ & $\mathrm{m}^{2}$ & + & \multirow{4}{*}{ (Ellis, 2008) } \\
\hline & $\begin{array}{l}\text { Status kepemilikan } \\
\text { rumah yang digunakan } \\
\text { untuk tempat tinggal }\end{array}$ & $\begin{array}{l}=1 \text { jika milik } \\
\text { sendiri, } \\
=0 \text { jika bukan } \\
\text { milik sendiri }\end{array}$ & + & \\
\hline & $\begin{array}{l}\text { Kepemilikan kendaraan } \\
\text { sepeda motor }\end{array}$ & $\begin{array}{l}=1 \text { jika memiliki, } \\
=0 \text { jika tidak } \\
\text { memiliki }\end{array}$ & + & \\
\hline & Kepemilikan mobil & $\begin{array}{l}=1 \text { jika memiliki, } \\
=0 \text { jika tidak } \\
\text { memiliki }\end{array}$ & + & \\
\hline $\begin{array}{l}\text { Persediaan } \\
\text { pangan }\left(\mathrm{x}_{15}\right)\end{array}$ & $\begin{array}{l}\text { Kepemilikan } \\
\text { persediaan pangan } \\
\text { domestik bagi rumah } \\
\text { tangga }\end{array}$ & $\begin{array}{l}=1 \text { memiliki } \\
\text { persediaan } \\
\text { pangan, } \\
=0 \text { tidak } \\
\text { memiliki }\end{array}$ & + & \multirow{2}{*}{$\begin{array}{l}\text { (Abeje et al., } \\
\text { 2019; Kassoe et } \\
\text { al., 2017) }\end{array}$} \\
\hline $\begin{array}{l}\text { Kecukupan } \\
\text { pangan }\left(\mathrm{x}_{16}\right)\end{array}$ & $\begin{array}{l}\text { Persepsi petani pada } \\
\text { kecukupan persediaan } \\
\text { terhadap kebutuhan } \\
\text { pangan rumah tangga }\end{array}$ & $\begin{array}{l}1 \text { jika merasa } \\
\text { akan tercukupi, } \\
=0 \text { jika merasa } \\
\text { tidak akan } \\
\text { tercukupi }\end{array}$ & - & \\
\hline
\end{tabular}

Misalnya, kotoran ternak untuk penyediaan pupuk organik, sedangkan jerami untuk penyediaan pakan ternak. Sementara itu, tanaman palawija juga dijadikan sebagai sumber pendapatan oleh hampir 50\% sampel rumah tangga tani padi. Palawija umumnya dijadikan sebagai tanaman yang dibudidayakan setelah panen padi, baik pada musim tanam kedua maupun musim tanam ketiga setiap periode tanam selama setahun. Terutama saat ketersediaan air untuk budidaya padi relatif terbatas, palawija juga menjadi komoditas alternatif. 
Pada sektor non-pertanian, kegiatan perdagangan menjadi pilihan utama bagi rumah tangga petani padi untuk dijadikan sebagai sumber pendapatan alternatif. Mengenai partisipasi rumah tangga tani pada kegiatan perdagangan, hal ini berkaitan dengan time constraint yang dimiliki oleh masing-masing rumah tangga, yang mana kedua kegiatan tersebut dapat dijalankan secara simultan dan tidak menuntut opportunity cost alokasi tenaga kerja dalam keluarga.

Sementara itu, dana transfer berupa remitansi juga menjadi sumber pendapatan penting bagi rumah tangga tani padi. Remitansi adalah bagian dari balas jasa yang diterima oleh rumah tangga yang anggota keluarganya bekerja di luar daerah atau luar negeri. Gambar 1 menunjukkan proporsi masing-masing sumber pendapatan berdasarkan jumlah rumah tangga tani padi yang berpartisipasi.

\section{Karakteristik Rumah Tangga Tani Padi}

Berdasarkan informasi yang ditampilkan pada Tabel 2, diketahui bahwa rerata IKS menunjukkan tingkat diversifikasi yang relatif rendah $(0,34)$. Sebagian besar $(87 \%)$ kepala rumah tangga petani padi di Provinsi Jawa Timur adalah laki-laki, dengan usia produktif (sekitar 52 tahun), dan hanya 22\% yang telah menyelesaikan pendidikan formal setingkat sekolah menengah atas (SMA). Pada aspek on-farm, rerata luas lahan pertanian yang dikuasai oleh rumah tangga tani adalah sebesar 3.977,82 $\mathrm{m}^{2}$, berarti ukuran ini menunjukkan bahwa secara general rumah tangga tani padi di Provinsi Jawa Timur tergolong sebagai petani gurem. Hambatan untuk memperoleh sarana produksi hanya dialami oleh $11 \%$ sampel dan berarti penyediaan input pertanian relatif menjangkau sebagian besar rumah tangga tani. Ditinjau dari kepemilikan asset, rumah yang ditinggali oleh sebagian besar rumah tangga tani adalah rumah milik sendiri dan sebagian besar dari mereka memiliki kendaraan bermotor berupa kendaraan roda dua. Sementara itu, ditinjau dari ketersediaan pangan domestik, mayoritas rumah tangga tani memiliki stok pangan dan hanya $11 \%$ dari sampel yang memiliki persepsi bahwa ketersediaan pangannya tidak mencukupi kebutuhan konsumsi pangan. Dengan demikian, status kecukupan pangan rumah tangga tani padi relatif tinggi.

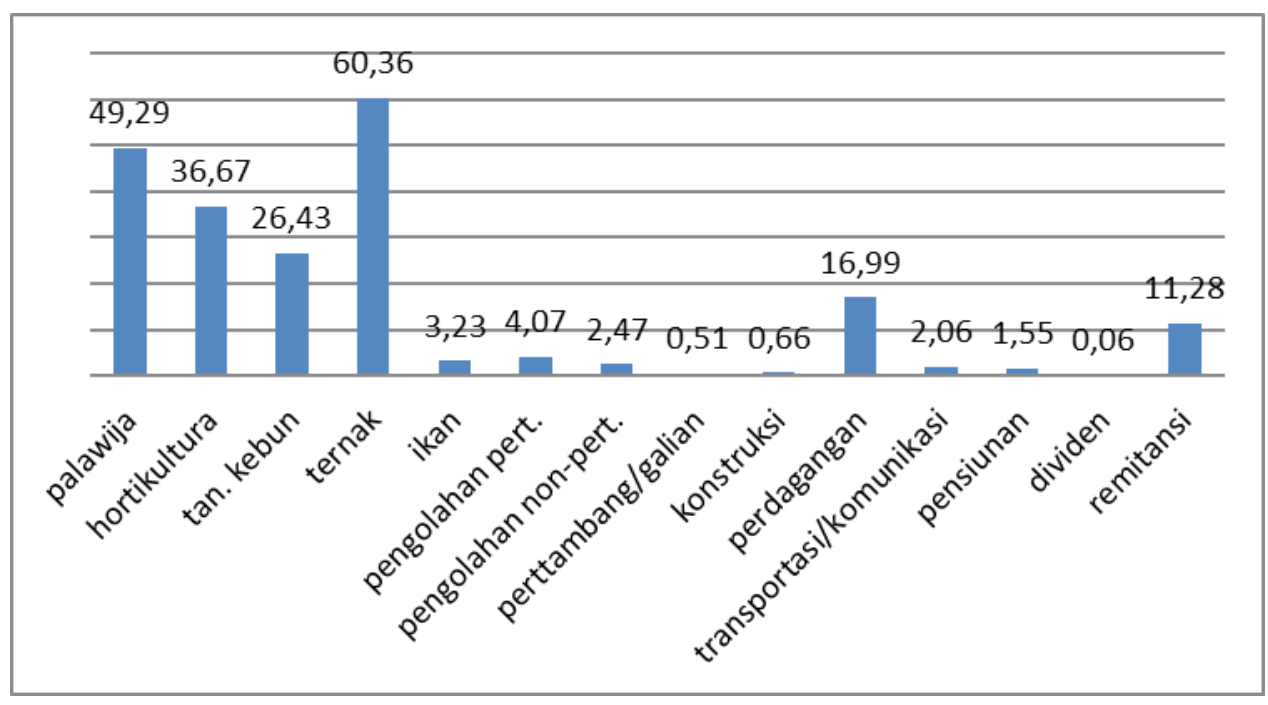

Gambar 1. Persentase Rumah Tangga Tani Padi Pada Berbagai Sumber Pendapatan Sumber: Komputasi data, 2019 
Tabel 2. Statistik Deskritif Variabel Analisis

\begin{tabular}{lrrrr}
\hline \multicolumn{1}{c}{ Variabel penjelas $(x)$} & \multicolumn{1}{c}{ Mean } & Standar Deviasi & Minimum & Maximum \\
\hline IKS $(\mathrm{y})$ & 0,34 & 0,231 & 0,00 & 0,83 \\
Gender $\left(\mathrm{x}_{1}\right)$ & 0,87 & 0,332 & 0 & 1 \\
Usia $\left(\mathrm{x}_{2}\right)$ & 52,27 & 13,060 & 16 & 98 \\
Pendidikan $\left(\mathrm{x}_{3}\right)$ & 2,60 & 1,480 & 0 & 1 \\
Anggota rumah tangga $\left(\mathrm{x}_{4}\right)$ & 0,22 & 0,415 & 0 & 15 \\
Lahan $\left(\mathrm{x}_{5}\right)$ & $3.977,82$ & $7.506,797$ & 465 & 24.766 \\
Hambatan input $\left(\mathrm{x}_{6}\right)$ & 0,11 & 0,307 & 0 & 1 \\
Kredit $\left(\mathrm{x}_{7}\right)$ & 0,08 & 0,277 & 0 & 1 \\
Penyuluhan $\left(\mathrm{x}_{8}\right)$ & 0,33 & 0,469 & 0 & 1 \\
Keanggotaan kelompok tani $\left(\mathrm{x}_{9}\right)$ & 0,20 & 0,396 & 0 & 1 \\
Keanggotaan koperasi $\left(\mathrm{x}_{10}\right)$ & 0,05 & 0,225 & 0 & 1 \\
Status kepemilikan rumah $\left(\mathrm{x}_{11}\right)$ & 0,97 & 0,178 & 0 & 1 \\
Luas area rumah $\left(\mathrm{x}_{12}\right)$ & 93,60 & 82,447 & 12 & 433 \\
Kepemilikan sepeda motor $\left(\mathrm{x}_{13}\right)$ & 0,74 & 0,438 & 0 & 1 \\
Kepemilikan mobil $\left(\mathrm{x}_{14}\right)$ & 0,06 & 0,235 & 0 & 1 \\
Persediaan pangan $\left(\mathrm{x}_{15}\right)$ & 0,80 & 0,397 & 0 & 1 \\
Kecukupan pangan $\left(\mathrm{x}_{16}\right)$ & 0,11 & 0,318 & 0 & 1 \\
\hline Sumber: Komputasi & & & &
\end{tabular}

Sumber: Komputasi data, 2019

Faktor-faktor penentu diversifikasi pendapatan rumah tangga tani padi

Hasil estimasi Censored Tobit Regression pada variabel penentu diversifikasi pendapatan (IKS) disajikan pada Tabel 3. Diversifikasi pendapatan rumah tangga tani padi ditentukan oleh faktor-faktor pada aspek karakteristik rumah tangga, onfarm, aset, institusi, serta ketersediaan pangan.

Jenis kelamin kepala rumah tangga lakilaki akan mengurangi probabilitas rumah tangga tani untuk melakukan diversifikasi pendapatan. Hasil ini sejalan dengan beberapa penelitian yang menemukan bahwa diversifikasi pendapatan semakin besar justru jika rumah tangga tani dikepalai oleh perempuan, dimana perempuan cenderung tidak terikat pada pengelolaan aset rumah tangga sehingga mereka lebih mudah untuk terlibat di berbagai macam kegiatan produktif (Agyeman et al., 2014). Hasil ini dikonfirmasi juga oleh karakteristik rumah tangga tani padi di Jawa Timur, dimana mayoritas kepala rumah tangga adalah laki-laki dan derajat diversifikasi pendapatan yang relatif rendah. Selanjutnya, analisis mengindikasikan bahwa probabilitas diversifikasi pendapatan rumah tangga tani akan meningkat jika jumlah anggota rumah tangga semakin banyak. Tentu, dengan sumber daya manusia yang lebih besar, kesempatan alokasi atau partisipasi ke berbagai kegiatan ekonomi akan semakin terbuka (Block \& Webb, 2001). Aspek karateristik rumah tangga berupa tingkat pendidikan rumah tangga menunjukkan pengaruh signifikan dan korelasi negatif dengan diversifikasi pendapatan. Penjelasan yang relevan adalah bahwa kepala rumah tangga tani yang telah menempuh tingkat pendidikan menengah atau yang lebih tinggi relatif dapat memanfaatkan teknologi pertanian yang lebih baik dan memperoleh peningkatan produktivitas pertanian. Hal ini yang mendorong mereka untuk berspesialisasi pada usaha budidaya pertanian. Demikian pula, penelitian sebelumnya menunjukkan bahwa pendidikan memiliki hubungan negatif pada diversifikasi pendapatan (Kassie et al., 2017)

Pada aspek usahatani, luas lahan pertanian yang dikelola dan hambatan untuk memperoleh saprodi secara signifikan memiliki dampak dan berkorelasi positif pada 
diversifikasi pendapatan. Ukuran lahan yang luas memberikan kesempatan bagi rumah tangga tani untuk melakukan diversifikasi pendapatan melalui pengelolaan berbagai macam komoditas. Hal ini merupakan perilaku umum bagi petani untuk memaksimalkan pendapatan dari sumber yang beragam (Ellis, 2008). Sebagaimana komposisi pendapatan rumah tangga tani padi di Jawa Timur, sumber pendapatan pertanian bukan hanya dari usahatani padi tetapi juga berasal dari pengelolaan tanaman palawija, hortikultura, tanaman kebun, ternak, dan perikanan.

Faktor penting yang juga menentukan tingkat diversifikasi pendapatan rumah tangga tani padi di Jawa Timur adalah partisipasi pada kegiatan penyuluhan, dimana sekitar $33 \%$ rumah tangga tani padi berpartisipasi di kegiatan penyuluhan. Keikutsertaan dalam kegiatan penyuluhan pertanian menurunkan probabilitas rumah tangga tani untuk melakukan diversifikasi pendapatan. Dengan tersedianya penyuluhan pertanian, maka keahlian dan kemampuan rumah tangga tani untuk mengelola usahatani semakin baik sehingga produktivitas yang lebih tinggi lebih mungkin untuk dicapai. Tingginya produktivitas usahatani pada suatu komoditas tertentu menjadi pendorong mereka untuk tetap berspesialisasi pada usahatani komoditas tersebut (Kassie, 2017; Rahut et al., 2014).

Berikutnya, pada aspek institusi, keanggotaan dalam kelompok tani cenderung mendorong rumah tangga tani untuk melakukan diversifikasi pendapatan.

Keikutsertaan dalam kelompok tani memberikan banyak insentif bagi rumah tangga tani di Jawa Timur, misalnya penyaluran subsidi pupuk, benih, dan bantuan pemasaran. Dengan adanya insentif tersebut, sesuai dengan temuan Kassie et al. (2017), kendala keuangan rumah tangga akan diminimalkan sehingga mereka memiliki kesempatan untuk berpartisipasi dalam

Tabel 3. Hasil Analisis Censored Tobit Regression (Variabel dependen= IKS)

\begin{tabular}{lrr}
\hline \multicolumn{1}{c}{ Variabel penjelas $(x)$} & Koefisien & p-value \\
\hline Gender $\left(\mathrm{x}_{1}\right)$ & $-0,012$ & $0,009^{* * *}$ \\
Usia $\left(\mathrm{x}_{2}\right)$ & 0,000 & 0,792 \\
Pendidikan $\left(\mathrm{x}_{3}\right)$ & $-0,008$ & $0,026^{* *}$ \\
Anggota rumah tangga $\left(\mathrm{x}_{4}\right)$ & 0,002 & $0,015^{* *}$ \\
Lahan $\left(\mathrm{x}_{5}\right)$ & 0,001 & $0,000^{* * *}$ \\
Hambatan input $\left(\mathrm{x}_{6}\right)$ & 0,024 & $0,000^{* * *}$ \\
Kredit $\left(\mathrm{x}_{7}\right)$ & 0,004 & 0,436 \\
Penyuluhan $\left(\mathrm{x}_{8}\right)$ & $-0,017$ & $0,000^{* * *}$ \\
Keanggotaan kelompok tani $\left(\mathrm{x}_{9}\right)$ & 0,031 & $0,000^{* * *}$ \\
Keanggotaan koperasi $\left(\mathrm{x}_{10}\right)$ & $-0,002$ & 0,762 \\
Status kepemilikan rumah $\left(\mathrm{x}_{11}\right)$ & 0,021 & $0,007 * * *$ \\
Luas area rumah $\left(\mathrm{x}_{12}\right)$ & 0,000 & $0,027^{* *}$ \\
Kepemilikan sepeda motor $\left(\mathrm{x}_{13}\right)$ & $-0,007$ & $0,046^{* *}$ \\
Kepemilikan mobil $\left(\mathrm{x}_{14}\right)$ & $-0,002$ & 0,700 \\
Persediaan pangan $\left(\mathrm{x}_{15}\right)$ & 0,007 & $0,040^{* *}$ \\
Kecukupan pangan $\left(\mathrm{x}_{16}\right)$ & 0,016 & $0,000^{* * *}$ \\
Prob. $\chi^{2}=0,000 ;$ Sseudo $R^{2}=0,87 ; \mathrm{n}=38.911$ & & \\
$* * *$ signifikan pada $\alpha=1 \% ;$ & & \\
$* *$ signifikan pada $\alpha=5 \%$ & & \\
\hline Sumber: Anas $\alpha t a, 2019$ & &
\end{tabular}

Sumber: Analisis data, 2019 
kegiatan penghasil pendapatan di luar kegiatan pertanian.

Pada aspek kepemilikan asset, rumah dan sepeda motor menjadi factor yang signifikan mempengaruhi diversifikasi pendapatan rumah tangga tani padi di Jawa Timur. Sebagaimana data yang ditampilkan oleh Tabel 2, bahwa sebagian besar rumah tangga tani padi di Jawa Timur memiliki rumah dan sepeda motor. Variabel status kepemilikan rumah dan luas area rumah secara signifikan menentukan diversifikasi pendapatan. Rumah tangga yang rumahnya berstatus milik sendiri memiliki ukuran yang layak cenderung melakukan diversifikasi pendapatan. Hal ini berkaitan dengan faktor rasa aman terhadap kepemilikan aset dan insentif berupa kepemilikan jaminan untuk memperoleh modal usaha dari lembaga keuangan untuk terlibat di kegiatan ekonomi selain usahatani (Abeje et al., 2019).

Aset berupa kendaraan roda dua justru menurunkan probabilitas rumah tangga tani untuk melakukan diversifikasi pendapatan. Hal ini mengindikasi bahwa kepemilikan kendaraan roda dua menjadi insentif bagi rumah tangga tani untuk berspesialisasi. Sebagaimana umumnya di kawasan perdesaan, kendaraan roda dua sangat membantu petani untuk menunjang kegiatan usaha taninya, misalnya sebagai alat angkut saprodi atau hasil panen. Kemudahan ini yang dapat meningkatkan produktivitas pertanian yang dikelola rumah tangga tani sehingga dorongan untuk diversifikasi tidak tumbuh.

Selanjutnya, kepemilikan stok pangan domestik dan kekhawatiran pada ketidakcukupan persediaan pangan mendorong rumah tangga tani untuk melakukan diversifikasi pendapatan. Di Jawa Timur, sekitar $80 \%$ rumah tangga tani padi memiliki persediaan pangan domestik tetapi hanya $11 \%$ yang merasa kebutuhan pangannya dapat dicukupi oleh persediaan pangan tersebut. Persediaan pangan domestik yang dimiliki menjadi kelonggaran bagi rumah tangga tani untuk berpartisipasi dalam berbagai kegiatan ekonomi, bukan hanya pada budidaya padi. Sumber daya yang dimiliki tidak digunakan untuk menambah alokasi sumber daya pada budidaya padi. Sementara itu, kekhawatiran pada ketidakcukupan pangan justru mendorong rumah tangga petani untuk melakukan diversifikasi pendapatan. Kondisi demikian, menurut Ellis (2008), menunjukkan bahwa mereka ingin memperoleh jaminan tambahan pendapatan dari kegiatan selain budidaya padi untuk meningkatkan kemampuan memenuhi kebutuhan konsumsi.

\section{SIMPULAN DAN SARAN}

Berdasarkan analisis menggunakan Indeks Keberagaman Simpson (IKS), derajat diversifikasi pendapatan rumah tangga petani padi di Provinsi Jawa Timur umumnya rendah. Walaupun demikian, IKS tetap mengindikasikan bahwa rumah tangga petani padi menghasilkan pendapatan mereka dari sumber mata pencaharian yang beragam. Jenis sumber pendapatan usahatani yang dimiliki oleh rumah tangga petani padi didominasi oleh usaha peternakan, budidaya palawija, dan budidaya hortikultura. Sementara itu, sumber pendapatan alternatif dari non-pertanian didominasi oleh perdagangan dan remitansi.

Faktor karakteristik yang signifikan menentukan tingkat diversifikasi pendapatan rumah tangga petani padi di Provinsi Jawa Timur kepala rumah tangga laki-laki, jumlah anggota rumah tangga, dan tingkat pendidikan kepala rumah tangga. Pada aspek on-farm, luas lahan yang dikelola untuk usahatani dan hambatan untuk memperoleh saprodi akan mendorong rumah tangga petani padi untuk melakukan diversifikasi pendapatan. Kegiatan pendukung berupa penyuluhan dan keanggotaan kelompok tani meningkatkan kemungkinan bagi rumah tangga tani untuk mendiversifikasi pendapatan rumah tangganya. Di samping itu, kepemilikan asset dan faktor ketersediaan pangan juga menentukan derajat diversifikasi pendapatan mereka.

Berdasarkan temuan penelitian ini, implikasi berupa pertanyaan bagi penelitian 
selanjutnya adalah bagaimana dampak diversifikasi pendapatan yang dilakukan oleh rumah tangga tani, khususnya petani padi, terhadap kinerja usahatani padi. Apakah terjadi trade-off atau justru diperoleh peningkatan kinerja usahatani padi sebagai sumber pendapatan utama. Jawaban atas pertanyaan ini akan mengkonfirmasi apakah upaya/strategi yang ditempuh rumah tangga tani padi untuk meningkatkan pendapatan dapat bersinergi dengan kepentingan penyediaan pangan, dalam hal ini beras. Selain itu, pertanyaan mengenai aktivitas apa saja yang dapat mendudukung peningkatan kinerja usahatani padi merupakan implikasi berikutnya. Kajian tersebut akan sangat diperlukan bagi penyusunan kebijakan yang sesuai dalam rangka meningkatkan pendapatan rumah tangga tani padi sekaligus menjamin produktivitas usahatani padi.

\section{UCAPAN TERIMA KASIH}

Penulis menyampaikan terima kasih kepada Badan Pusat Statistik atas penyediaan data yang digunakan dalam penelitian ini.

\section{DAFTAR PUSTAKA}

Abeje, M. T., A. Tsunekawa, E. Adgo, E, N. Haregeweyn, Z. Nigussie, Z. Ayalew, A. Elias, D. Molla dan D. Berihun. 2019. Exploring drivers of livelihood diversification and its effect on adoption of sustainable land management practices in the upper Blue Nile basin, Ethiopia. Sustainability (Switzerland) 11(10). https://doi.org/10.3390/su11102991

Adelekan, Y. A., dan A. O. Omotayo. 2018. Linkage between rural non-farm income and agricultural productivity in Nigeria : a tobit-two-stage least square regression approach. The Journal of Developing Areas 51(3): 317-333.

Agyeman, B. A. S., S. Asuming-Brempong dan E. E. Onumah. 2014. Determinants of income diversification of farm households in the Western Region of Ghana. Quarterly Journal of International Agriculture 53(1): 55-72.

Alobo L. S. 2015. Rural livelihood diversification in Sub-Saharan Africa: A Literature Review. Journal of Development Studies 51(9): 1125-1138. https://doi.org/10.1080/00220388.2015. $\underline{1046445}$

BPS. 2015. Statistik Indonesia 2014. Badan Pusat Statistik.

Bappenas. 2014. Analisis Rumah Tangga, Lahan, dan Usaha Pertanian di Indonesia: Sensus Pertanian 2013. Badan Perencanaan Pembangunan Nasional.

Barrett, C. B., T. Reardon dan P. Webb. 2001. Nonfarm income diversification and household livelihood strategies in rural Africa : concepts, dynamics, and policy implications. Food Policy 26: 315-331.

Bezu, S., C. B. Barrett dan S. T. Holden. 2012. Does the nonfarm economy offer pathways for upward mobility? evidence from a panel data study in Ethiopia. World Development 40(8): 1634-1646.

https://doi.org/10.1016/j.worlddev.2012. 04.019

Block, S., dan P. Webb. 2001. The dynamics of livelihood diversification in postfamine Ethiopia. Food Policy 26(4): 333-350.

Dercon, S. 2002. Income risk, coping strategies, and safety nets. The World Bank Research Observer 17(2): 141166.

https://doi.org/10.1093/wbro/17.2.141 
Ellis, F. 1998. Household strategies and rural livelihood diversification. Journal of Development Studies 35: 1-38.

Ellis, F. 2008. The determinants of rural livelihood diversification in developing countries. Journal of Agricultural Economics 51(2): 289-302. https://doi.org/10.1111/j.14779552.2000.tb01229.x

FAO. 2015. The State of Food Insecurity in the World 2015. Meeting the 2015 International Hunger Targets: Taking Stock of Uneven Progress. FAO.

Green, W. 2003. Econometrics Analysis. Prentice Analysis.

Haggblade, S., P. Hazell dan T. Reardon. 2010. The rural non-farm economy: prospects for growth and poverty reduction. World Development 38(10): 1429-1441.

https://doi.org/10.1016/j.worlddev.2009. $\underline{06.008}$

Joshi, P. K., A. A. Gulati, P. S. Birthal dan L. Twari, 2003. Agriculture diversification in South Asia: Pattern, Determinants and Policy Implications. Discussion Paper No. 57. Market Structure studies Divison, International Food Policy Research Institute.

Kassie, G. W. 2017. Agroforestry and farm income diversification: synergy or trade -off? The case of Ethiopia. Environmental Systems Research. https://doi.org/10.1186/s40068-017$\underline{0085-6}$

Kassie, G. W., S. Kim, S dan F. P. Fellizar. 2017. Determinant factors of livelihood diversification: Evidence from Ethiopia. Cogent Social Sciences 3(1): 1-16. https://doi.org/10.1080/23311886.2017. 1369490
Kerua, W. 2019. Livelihood diversification and its impact on cocoa production in Morobe and East New Britain Provinces of Papua New Guinea. International Journal of Agricultural Extension 7(1): 117-124. https://doi.org/10.33687/ijae.007.01.279 $\underline{3}$

Lanjouw, J. O dan P. Lanjouw. 2001. The rural non-farm sector: issues and evidence from developing countries. Agricultural Economics 26(1), 1-23. https://doi.org/10.1016/S0169$\underline{\text { 5150(00)00104-3 }}$

Minot, N., M. Epprecht, T. T. T. Anh dan Q. L. Trung. 2006. Income diversification and poverty in the northern uplands of vietnam. IFPRI Research Report 145.

Mishra, A. K dan C. B. Moss. 2013. Modeling the effect of off-farm income on farmland values: A quantile regression approach is. Economic Modelling 32: 361-368. https://doi.org/10.1016/j.econmod.2013. $\underline{02.022}$

Nguyen, A. T., L. T. Nguyen, H. H. Nguyen, H. V. Ta, H. V. Nguyen, T. A. Pham, B. T. Nguyen, T. T. Pham, N. T. T. Tang dan L. Hens. 2019. Rural livelihood diversification of Dzao farmers in response to unpredictable risks associated with agriculture in Vietnamese Northern Mountains today. Environment, Development and Sustainability, July. https://doi.org/10.1007/s10668-01900429-x

Niehof, A. 2004. The significance of diversification for rural livelihood systems. Food Policy 29(4 SPEC.ISS.): 321-338.

https://doi.org/10.1016/j.foodpol.2004.0 $\underline{7.009}$ 
Nigussie, Z., A. Tsunekawa, N. Haregeweyn, E. Adgo, M. Nohmi, M. Tsubo, D. Aklog, D. T. Meshesha dan S. Abele. 2017. Factors influencing small-scale farmers' adoption of sustainable land management technologies in northwestern Ethiopia. Land Use Policy 67(May): 57-64. https://doi.org/10.1016/j.landusepol.201 $\underline{7.05 .024}$

Rahut, D. B., A. Ali, M. Kassie, P. P. Marenya dan C. Basnet. 2014. Rural livelihood diversification strategies in nepal. Poverty \& Public Policy 6(3): 259-281. https://doi.org/10.1002/pop4.75

Schwarze, S., dan M. Zeller. 2005. Income diversification of rural households in Central Sulawesi, Indonesia. Quarterly Journal of International Agriculture 44(1): 61-73.

Start, D. 2001. The rise and fall of the rural non-farm economy: poverty impacts and policy options. Development Policy Review 19(4): 491-505. http://dx.doi.org/10.1111/1467$\underline{7679.00147}$

UN. 2015. The 2015 Revision ofthe UN's World Population Projections. Wiley Black well.

Wan, J., R. Li, W. Wang, Z. Liu dan B. Chen. 2016. Income diversification: A strategy for rural region risk management. Sustainability (Switzerland) 8(10): 112. https://doi.org/10.3390/su8101064

Woldehana, T. 2002. Rural farm/non-farm income linkages in northern Ethiopia. Promoting Farm/Non-Farm Linkages for Rural Development Case Studies from Africa and Latin America 121144.

Xing, Z. 2018. Development impacts of remittances in agricultural households: fiji experience. Remittances Review 3(1): 19-49.

https://doi.org/10.33182/rr.v3i1.425

Zhao, J., dan P. J. Barry. 2014. Income diversification of rural households in China. Canadian Journal of Agricultural Economics 62(3): 307-324. https://doi.org/10.1111/cjag.12033 